\section{Glory of Indian railways}

\author{
Soumya Chippagiri (1)
}

Indian railways are known to be one of the largest in the world. So much so that it has two UNESCO World Heritage Sites. It was the pandemic, coronavirus disease 2019 (COVID-19) that brought this lifeline to a standstill in 167 years. India being the resilient and innovative country that it is, has left no stone unturned to curtail the spread and control the infection. The trains are converted to COVID wards. Each coach is well armed to accommodate at least 16 patients, one doctors and nursing station each, space for medical equipment and facility for sanitation. This coach is enabled to navigate to the deepest parts of the country in case of a spike in COVID-19 cases when the hospitals are overwhelmed. Acting as a mobile ward, it transport patients when necessary from rural to the healthcarerich urban areas. Indian trains are being used in a healthful manner since 1991 with the Lifeline Express or Jeevan Rekha Express.

Contributors SC is the sole contributor of this article. Competing interests None declared.

Department of Community Health, St. John's Medical College, Bangalore, India

Correspondence to Correspondence to Soumya Chippagiri, Department of Community Health, St. John's Medical College, Bangalore, Karnataka, India; soumya.chippagiri87@gmail.com

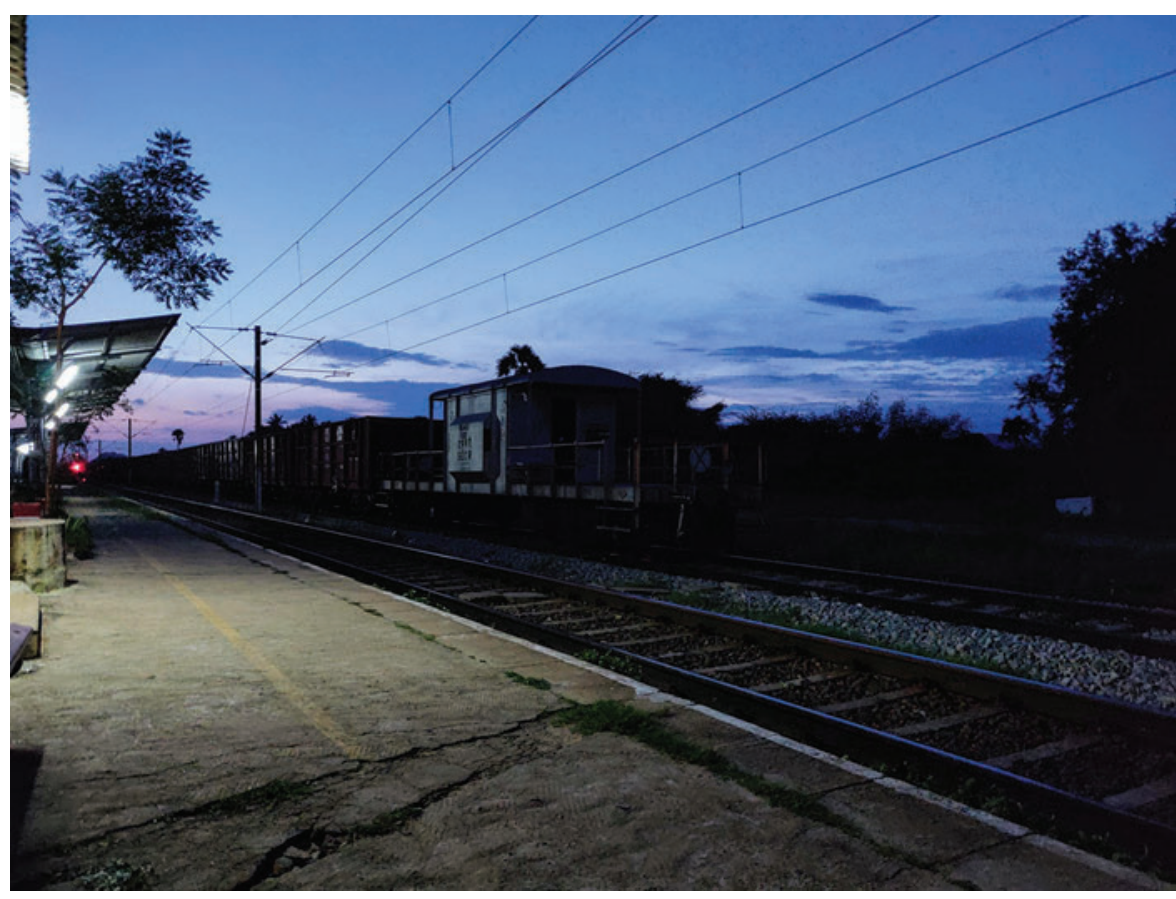

Figure 1 A train to battle pandemic.

Provenance and peer review Not commissioned; internally peer reviewed.

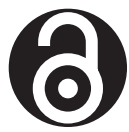

\section{OPEN ACCESS}

Open access This is an open access article distributed in accordance with the Creative Commons Attribution 4.0 Unported (CC BY 4.0) license, which permits others to copy, redistribute, remix, transform and build upon this work for any purpose, provided the original work is properly cited, a link to the licence is given, and indication of whether changes were made. See: http:// creativecommons.org/licenses/by/4.0/.
(C) Author(s) (or their employer(s)) 2021. Re-use permitted under CC BY. Published by BMJ.

A) Check for updates

To cite Chippagiri S. J Epidemiol Community Health 2021;75:484.

Received 28 May 2020

Revised 30 May 2020

Accepted 30 May 2020

Published Online First 30 June 2020

J Epidemiol Community Health 2021;75:484. doi:10.1136/jech-2020-214734

ORCID iD

Soumya Chippagiri http://orcid.org/0000-0002-0412-7397 